\title{
Population Pressure, Internal Migration, and the Process of »Modernization» in a Rural Community (Selånger) in Northern Sweden $1860-1910^{1}$
}

\section{LARS-GÖRAN TEDEBRAND}

\author{
Professor \\ Department of Historical Demography \\ University of Umeå
}

\section{Introduction}

A rather close connection between business cycles and migration in Sweden after 1870 has been established. The increasing net migration gains of towns and rural industrial communities on behalf of purely rural or mixed rural communities have been treated quite in detail primarily by use of aggregated data (D.S. Thomas, 1941 and Population movements and industrialization. Swedish counties $1895-1930,1941)$. Within the framework of the Uppsala migration project $(1966-1976)$ the seasonal labor migrations, internal and external migration in Sweden 1860-1910 have been related to the industrialization and urbanization process in a number of local case studies (Nilsson, 1970; Rondahl, 1972; Tedebrand, 1972; Norberg- ̊kerman, 1973; Norman, 1974; Kronborg-Nilsson, 1975; Rolén et al., 1979).

This article deals with historical (1860-1910) rural-rural, rural-industrial and rural-urban migration on parish level in northern Sweden. The connection between population pressure, internal migration and the "modernization» process in rural areas close to urban and industrial centres is in focus. The theoretical framework of the study is not elaborated in detail. Starting from a rather simple pull and push model and approach is however made in which the migration is placed in a matrix of social change.

\section{The problem}

Traditional pull and push mechanisms have been applicated in the analysis of rural-urban and rural-industrial migration balances. The perspective has, however, mostly been seen from the viewpoint of towns and rural communities under rapid industrialization (Rondahl, 1972; Kronborg-Nilsson, 1975). Rural communities have mostly been seen as losers in that contest. As far as the »pure» agricultural parishes in Sweden are concerned their conservative migration behavior has been stressed. In his classical study of the migration of Asby in middle Sweden 1840-1944 T. Hägerstrand underlined the permanence of the migrational behavior of rural populations: the short distance migration dominated during the whole period investigated and no net gains in the migration exchange could be identified (T. Hägerstrand, 1947).

In this article a shift of perspective will be made. The interest will be focused upon a non-industrial community within the urban and industrial »nearzone». The

${ }^{1}$ I am grateful to Dr. Lars-Erik Borgegård for comments on this article. 
study can be seen as a contribution to the question of the role and function of the geographically well situated agrarian »near-zone» during the industrialization and "modernization» of Sweden. Our area of investigation will be the parish of Selånger in northern Sweden, situated immediately to the west of the town of Sundsvall and the big saw-mill district south and north of that city (see maps). The Sundsvall district underwent a rapid growth during the period 1860-1890. The area is in fact an avantgarde area in the history of Swedish capitalism and industrialization. The first big industrial strike in Sweden took place here in 1879, when more than 5000 saw-mill workers were involved. The saw-mill parishes to the north and south of Sundsvall increased their population from 7406 inhabitants in 1860 to 28670 in 1890 . Crofters, sons of farmers, and landless laborers came by thousands from western and northern Sweden and even from Ostrobothnia in Finland to find work in the saw mills and timber yards of the Sundsvall district, which became known as a »little America» in Sweden during the boom years. Also the town of Sundsvall expanded rapidly as a commercial and administrative centre for the saw-mill industrialization. Selanger was not affected by the rapid industrialization in the neighborhood. Up to 1950 the only industry in the community was two small brickyards. Indirectly the community, however, was affected by the urbanization and industrialization in the neighborhood.

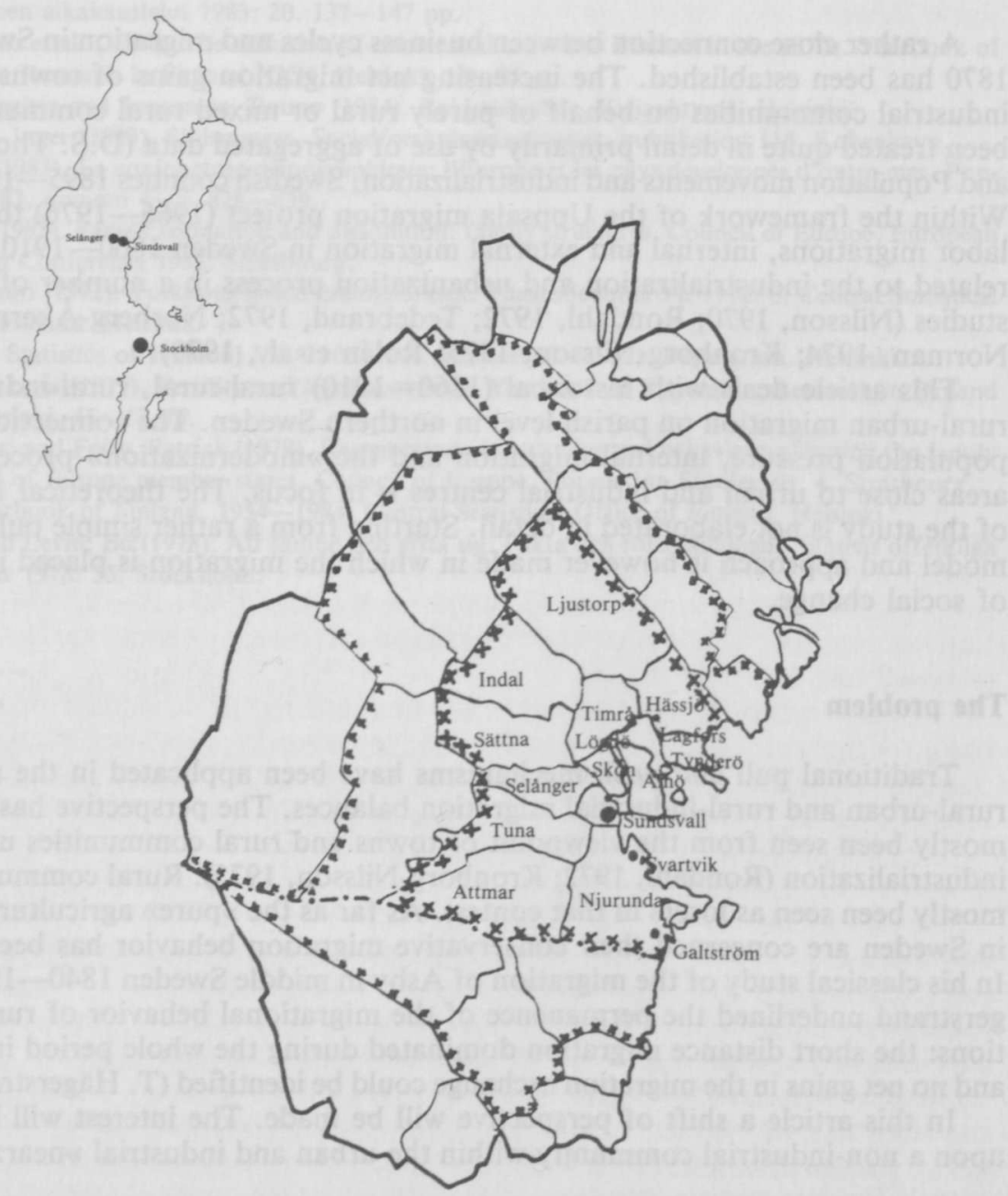

The parishes of the Sundsvall region. 


\section{Hypotheses}

The hypotheses of this paper are:

a) the agrarian »nearzone» has played a more independent and active role in the migrational processes than earlier assumed

b) this independent and hitherto rather neglected role is closely connected with the "modernization" process of the agrarian communities within the influence field of urban and industrialized areas.

\section{The »modernization» of Selånger}

Since long agriculture was considered a non-dynamic part of Swedish economy. Its contribution was mainly, according to deep rooted opinion, to be located to the large commercial houses in Gothenburg and Stockholm and to some of the subsidized industries in the towns but above all to the ironworks of the countryside. The Swedish ironworks filled, as it is well known, a large place on the European market even at the beginning of the 19th century. Early they had wage earners and became dependent upon additional capital supply from outside. It is only recently pointed out by economists-historians that the growing difference between land rates and taxes and prices of agricultural goods even in the latter part of the 18th century had accumulated a capital surplus within agriculture (Herlitz, 1974). Well situated farmers and landed proprietors had already in the beginning of the 18th century adopted a more capitalistic view of production. Marketing the output became increasingly important. The farmers began to employ free workers recruited from the fast growing masses of landless agricultural lower class people. At the estates situated in the valley around the Lake Mälaren near Stockholm, the earlier peasants of nobility and crofters were replaced by regularly yearly-employed farm workers called »statare» (Eriksson-Rogers, 1978). The feudal rent is replaced by a capitalistic land rent.

No one has come to think of the possibility of the rural society of northern Sweden having played an important role in this process. Our local commnity, Selånger, is certainly on the whole still a traditional society by 1850 . The social structure is dominated by peasant proprietors. The »medium-sized and big» peasants possess the political power. The registered migration of the population shows a clear dominance for the short distance migration. Production for the market is still small. The community is a rather closed cultural unit. The view of moral norms and hierarchical structure of the society was assumed to be shared by all citizens and was founded on the norms of the catechism of Martin Luther.

Long before the 18 th century, however, we have clear dynamic features in this society. Starting by the middle of that century the »modernization process» powerfully breaks through. It is a well known fact that the word "modernization» is an often misused concept. It has with some right been called an umbrella »to shelter a miscellany of less ambitious ideas» (E.A. Wrigley, 1972). It has also primarily been used to measure changes on aggregated national levels. According to my opinion it can be used as a tool to measure tendencies even on local levels. An operational definition of »modernization» can look like this: Indications of »modernization» are increased specialization in work as well as differentiation on the whole, higher educational level, increased social mobility and migration, more industrialization and urbanization, a growing public sector and per capita income and secularization, a lower pressure against uniformity, a higher political consciousness, a rising number of organizations, changed family combinations, and so forth.

Twelve variables have been chosen to illustrate the dicotimy between tradition and transition in Selånger (Figure 1, p. 88). As can be seen the modernization of our local agrarian community is a lengthy process. Some changes started already before 1750 , others are postwar phenomena. It is also quite clear that factors within the society itself have changed with external factors in promoting that process. The variables 
F i g u r e 1. The »modernization» of Selånger after 1700 .
1. Demographic transition
2. Social differentiation
3. Rationalization of agriculture
4. Migration
5. Education
6. Political power
7. Political mobilization
8. Organization life
9. Mentality
10. Urbanization
11. Public sector
12. Bureaucracy

$\begin{array}{lllll}1700 & 1750 & 1800 & 1850 & 1900\end{array}$

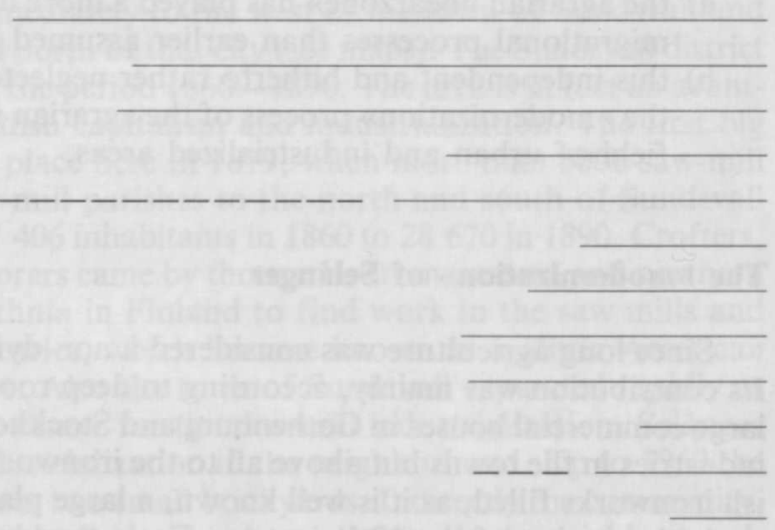

will now be briefly commented one by one with special emphasis on the introduction phase of the different modernization criteria.

\section{Demographic transition}

The demographic transition is perhaps the most intervening event in Western Civilization. Its social and economic implications for our local community can hardly be overstressed. After a slow population increase during the 16 th and 17 th centuries, where especially the 17 th century showed many repercussions in the population movement, the population of Selånger doubled between 1750 and 1850 or from 636 to 1459 persons. By 1910 the population had increased to 2849 inhabitants. The population growth up to 1870 was wholly dependent on a growing birth surplus, while the net migration played no role. As a matter of fact Selånger already in the 18 th century gets a rather modern $»$ reproduction profile». The mortality rate seldom was higher than the birth rate. No real connections between bad crops and mortality can be established after 1750. The last big epidemic appeared in 1785 (dysentery) when $10 \%$ of the population died. The last small pox epidemic occurred in 1800 .

The inhabitants' own ability to moderate the mortality rates must be stressed. Some major examples will be given. Already in 1798 the parish meeting hired a midwife who assisted by deliveries and instructed the mothers to nurse their children, as is well known the best profylax against high infant mortality. In 1805 the parish meeting decided that all children in the parish should be vaccinated against smallpox. During the famine years of the late 1860 s, which hit some remote areas in Sweden very hard, the ruling group of farmers made an inventory of the need of grain in every single household in the community and thereafter bought supplies from merchants in middle Sweden by raising a loan of 10000 Swedish crowns from the newly established banks in Sundsvall.

As far as the fertility decline is concerned there are no real indications - qualitative or quantitative - that the farming population in our community generally practised family limitation before the 1920 s and 1930 s. The fertility decline - whether it should be seen as an innovation or as an adjustment process - actually came later in northern Sweden than in other parts of the country. The inheritance customs the eldest son as a rule took over the farm - exerted only slight influence upon the size of the families in Selånger before World War I. 


\section{Social differentiation}

The population increase - a result of the mortality decline - leads to a press against the space of cultivation and to social differentiation already from the middle of the 18th century. Despite partition of the farmsteads and despite breaking up of new land it is not possible to absorbe the strong population and at the same time to keep the old social structure unchanged.

The population pressure against the soil 1750 - 1900 can be divided into three phases. A first phase is characterized by partition of farms and culminates already around 1800 . The second phase is distinguished by a growing number of crofters outside the old villages. In 1850 there are 106 farmers and 73 crofters, the latter often sons of farmers without opportunity to become freeholders. The third phase, after 1850 , is characterized by a rapid growth of the landless population and by laborers depending for their living on seasonal works at the big farms and the shipyards and the sawmills of the Sundsvall district. We are now also facing a considerable immigration of workers who have their daily work in Sundsvall.

At the end of the 19th century the gulfs within the landowning farmers themselves are growing. The old »democratic» structure of the society begins to be undermined. The well-to-do farmers produce for the growing market in Sundsvall and the industrial district. They can afford to hire more farmhands and the household size increases among many of them. They also sell timber to the sawmill industry. From private archives of the farmers we can see that the most well situated farmers invest their growing surplus of capital in the shipyards and the banks of Sundsvall. Sometimes they appear as private bankers vis-à-vis the crofters and the landless population. Many farmers begin to build more representative houses than before with more rooms and better furniture, and so on. We can also register an increasing number of real-estate purchases. Farmers from more remote parishes move in to Selånger in order to exploit the good consumer market in the neighborhood. The old family soil gets new owners.

The period between the wars and especially the postwar period is characterized by a rapid reduction of the farming population in Selånger, a common trend in rural Sweden at that time. The class of crofters transmutes into a wage-earning class. As a matter of fact the number of agricultural units diminishes from 400 in 1927 to only 95 in 1976 . In 1960 no more than $13 \%$ of the population earned their living from the soil of Selånger.

\section{Rationalization of agriculture}

The social differentiation, the growing socioeconomic gulfs and the rapid decrease of the agricultural population are, of course, closely related to the rationalization of agriculture. The mechanical rationalization of agriculture which disengages labor force is, of course, primarily located to the interwar and postwar period but it must be strongly stressed that the dynamic tendencies within agriculture in Selånger a response to the growing market orientation already from $1750-$ are considerable long before. At the end of the 18th century a lot of smaller fairs are established in the neighborhood of Sundsvall. The farmers begin to grow potatoes, diminishe the fallow fields and improve the threshing methods. The local society took a very strong initiative in the 1830 s when many villages began to redistribute the land through the so called 'Laga skifte', i.e. legal redistribution of land enacted by the Swedish Riksdag (the Parliament) in 1827. This brought about a dissolution of the village settlements and a certain change in the old village organization. No doubt the redistribution of land laid the foundation for the spread of a more "capitalistic» system in the agriculture of our community as well as in other parts of Sweden. To a certain, but often overestimated degree, the land redistribution also promoted out-migration of some farmers from the old villages. 
At the end of the 19th century the more progressive farmers took some very foreseeing initiatives. They began to use iron ploughs, threshing machines, introduced crop rotation, and founded a producers' association. In the 1890 s two dairies were started with more than 50 members who delivered butter and milk to the households in Sundsvall and the industrial district.

The machine rationalization went further in the 1920 s and 1930 s - the first tractor, an American Fordson Major, appeared in 1923 and the first mechanical binder somewhat later. It was very common that two or three farmers mutually financed the expensive machines. However, the labor saving machines became more common in the postwar period, especially in the 1960 s, and are now definitely related to reduction of the small farms and the "flight» of the labor force from agriculture.

\section{Migration}

Since hundreds of years the farmers of Selånger had travelled in wintertime to middle Sweden in order to dispose their small surplus from the agriculture, hunting, and fishing. They had also had carting jobs for the Swedish Crown and the small iron foundries in the neighboring parishes. However, the regular migration of Selånger up to 1850 was dominated by short distance migration of farm hands and maidservants in which in- and out-migration balanced each other. Until 1847 the parish meeting also possessed the right to refuse in-migration of unwanted persons whom the ruling farmers feared should burden the poor relief of the community. The old migration pattern was changed from about 1860 as a result of the "modernizing» tendencies we are discussing. The migration field extends widely and the net gains of the migration contribute considerably to the strong population increase of the community. This independent and active migrational behavior of the parish - rather untypical for rural communities before World War I - will soon be treated more in detail.

\section{Education}

Already long before the establishment of the first elementary school in Selånger in 1848 the inhabitants - due to the education of the Lutheran church and the parents, especially the mother - could read. Some sons of farmers did even study at the University of Uppsala. At the end of the 19th century the old »home education» was definitely replaced by the growing number of elementary schools in the parish. The youth of the landowning population began to study courses at particular training colleges. A parish library was established, clubs of discussion started, the spread of the two daily newspapers in Sundsvall increased, and so on. After the turn of the century the schools (through new school houses and the school reforms of the Swedish Riksdag) have been one of the heavy 'posts' in the budget of the community. The higher education has also been more 'democratized' after the Second World War.

\section{Political power}

The political power in Selånger before 1850 lay in the hands of the middle-sized and well-to-do farmers. They exerted a very severe social control upon the landless population: controlled its moral behavior, regulated its family size by prohibiting adult children of crofters and laborers to stay by their parents, and so forth. Despite the social differentiation in the community and despite new voting rules in Sweden the farmers - from 1920 swifting from the Liberals to the Farmers party founded in 1917 - were in power up to the election in 1934, when the Social Democrats won the majority among the voters. The take-over of the Social Democrats was a result of the increase of the labor population and the radicalization of the agricultural workers and small farmers during the depression of the 1930s. As a matter of fact 
the Social Democrats kept the political power until 1958 when a bourgeois coalition took over the government of the community.

\section{Political mobilization}

Before 1900 political activity had primarily been an affair for the ruling elite of farmers. By the turn of the century the general political interest in the community grew tremendously. This political mobilization is intimately associated with the breakthrough of the temperance movement and of the free churches (baptists, methodists). The opposition of the farmers against the lumber companies of the Sundsvall district and their acquisition of farmsteads also swifted over the majority of the farmers from conservatism to liberalism. In the general election of $191175 \%$ of the - by that time only male - voters backed the Liberals.

\section{Organization life}

Within Swedish research the breakthrough of the voluntary mass associations, as the temperance movement and the free churches, has mostly been connected with urbanization and industrialization. However, the organizational activity started early even in the agrarian milieu. As already mentioned a producers' association, with predecessors down in the $1850 \mathrm{~s}$, was founded in 1901. Almost a third of the adult population of Selånger belonged to the different temperance associations in 1910, only 15 years after their first appearance in the community.

The »old» popular movements - the temperance associations and the free churches - reached their maximum membership already before World War I. The interwar period is characterized by the organization of workers and farmers. The brickyard workers founded a union already in 1907 but it was dissolved during the General Strike in Sweden in 1909 which came to be a defeat for the labor movement in the country. The union was not re-established until 1921. The Social Democratic Party founded a local committee in 1926. It strongly increased its member stock during the depression in the beginning of the 1930s. During the depression years the farmers' cooperative organizations also flourished. As in other parts of Sweden today's Selånger is a very well organized society with nearly every adult person being a member of a union or an winterest» organization.

\section{Mentality}

In »old» Selånger the parish priest had been the only announcer. From the second half of the 19th century he faced competition from temperance speachers and free church preachers. The formerly hard repression of the parish meeting against non-wanted moral and social behavior diminishes. The parish catechetical meeting is not so numerously attended any longer as the prevalent secularization increases among the inhabitants, especially among the crofters and workers. The general opinion among the farmers swifts, as has already been mentioned, from traditional conservatism to liberalism and strong antagonism against the activities of the lumber companies. The farmers accept bourgeois standards in furniture, clothing, and naming-system. The increasing labor population begins to listen to the message of socialism spread from the sawmill district and the city of Sundsvall. The development towards secularization and dissolution of old patriarchial attitudes then grows much stronger during the interwar period.

\section{Urbanization}

Already before World War I some of the villages of Selånger in the near of Sundsvall were becoming rather independent from agriculture (brickyard workers and ped- 
dlers). This development increased during the interwar period and especially after the Second World War. In 1955 nearly $60 \%$ of the wage-earning population of Selånger worked in Sundsvall. Agrarian Selånger met the problems of urbanization: housing, outflow, street planning, and so on. Selånger of today has to a very high extent become a suburb to the city of Sundsvall.

\section{Public sector}

The growth of the public sector already began at the end of the 19th century. Between 1885-1914 the budget of Selannger was doubled as a result of the growing costs for schools and poor relief. During the interwar period the Swedish Parliament laid new burdens upon the local communities but at the same time the latter could take advantage of government subvention for their activity. The enlargement of the Swedish welfare state in the postwar period has strongly promoted the expension of the public sector.

\section{Bureaucratization}

Selånger had, like other agrarian communities, very few salaried officeholders before the Second World War. The ruling farmers had a strong fear for cash expenditures. Public duties were performed on a voluntary basis. The rise of a communal bureaucracy has been a very rapid process located to the 1950 s and 1960 s and shall, of course, be seen as a natural result of the above mentioned growth of the public sector.

\section{Two-way migration and »modernization»}

The »modernization» of Selånger has, as already mentioned, been a lengthy process, in some cases dating back to 1750 . Its connection with migration $1860-1910$ will now be dealt with more in detail. Already from the beginning we must keep in mind that Selånger up to World War I was an agrarian community untouched by industrialization but within the influence zone of an expanding urban and industrial district.

As the population in Selånger grew during the early phase of the demographic transition the population pressure made itself manifest. The following solutions are to be considered:

1. Outmigration

2. Fertility reduction

3. Agricultural innovation

4. Non-agricultural diversification

5. Some combinations of the above mentioned solutions

As a result of the pull from the labor market in the sawmill district and the city of Sundsvall during the boom years $1860-1890$ one should expect a strong outmigration from Selånger. This was, however, not the case. Neither was the fertility reduction operative. Agrarian Selånger instead succeeded in profiting from the expansion of the dynamic neighborhood. Agricultural innovation and non-agricultural diversification came to be the response to population pressure instead of outmigration and fertility reduction. The community was to a very high degree situated in a hinterland of a city and an industrialized area. Von Thünen's well-known system of land use might therefore be applicable.

The local society became more market oriented than before and took many steps in modernizing the old structure. By doing so it could resist the expansion of the lumber companies and prevent outmigration. Selånger was in other words far from 
a passive loser in the migrational processes of the early industrialization in northern Sweden.

Before discussing the migration we will give a survey of Selångers population development 1860-1910 (Table 1).

T a b l e 1. The population of Selånger every ten years $1860-1910$ among men and women. Percental change in every ten-year-period.

$\begin{array}{rrccc}\text { Year } & \text { Men } & \text { Women } & \text { Total } & \text { Percental change } \\ 1860 & 714 & 745 & 1459 & \\ 1870 & 736 & 765 & 1501 & 2.9 \\ 1880 & 1006 & 973 & 1979 & 31.8 \\ 1890 & 1312 & 1267 & 2579 & 30.3 \\ 1900 & 1344 & 1298 & 2642 & 2.4 \\ 1910 & 1420 & 1429 & 2849 & 7.8\end{array}$

The favorable population development of Selånger during the early phase of industrialization is quite clear when compared with the population increase in all types of communities in the province of Västernorrland (Table 2).

$\mathrm{T}$ a b l e 2. Population by the end of every five-year-period in industrial parishes, mixed parishes, agricultural parishes and »company» parishes in the province of Västernorrland and in the country as a whole $1875-1910$. Changes after five years are given in percent.

\begin{tabular}{|c|c|c|c|c|c|c|c|c|c|}
\hline \multicolumn{2}{|c|}{$\begin{array}{l}\text { Industrial } \\
\text { parishes }\end{array}$} & \multicolumn{2}{|c|}{$\begin{array}{l}\text { Mixed } \\
\text { parishes }\end{array}$} & \multicolumn{2}{|c|}{$\begin{array}{l}\text { Agricultural } \\
\text { parishes }\end{array}$} & \multicolumn{2}{|c|}{$\begin{array}{c}\text { "Company" } \\
\text { parishes }\end{array}$} & \multicolumn{2}{|c|}{$\begin{array}{l}\text { The country } \\
\text { as a whole }\end{array}$} \\
\hline Population & $\%$ & Population & $\%$ & Population & $\%$ & Population & $\%$ & Population & $\%$ \\
\hline 44589 & & 23087 & & 20621 & & 49480 & & 4383291 & \\
\hline & +19.4 & & +8.5 & & +6.5 & 5497 & +11.1 & & \\
\hline 61788 & +16 & & +5 . & & +4.2 & 581 & +5.9 & & \\
\hline $\begin{array}{l}72673 \\
75150\end{array}$ & +17.6 & & +8.2 & 239 & $\begin{array}{r}+4.9 \\
+3.1\end{array}$ & 0 & $\begin{array}{l}+9.0 \\
+1.5\end{array}$ & $\begin{array}{l}81 \\
260\end{array}$ & \\
\hline & $\begin{array}{l}+3.4 \\
+11.3\end{array}$ & & $\begin{array}{l}+3 . \\
+6 .\end{array}$ & & +0 & 67066 & +4.2 & 5136 & \\
\hline 87028 & +4.0 & 32055 & +2.4 & & +0.6 & 68841 & +2.6 & 5294885 & 3.1 \\
\hline 91718 & +5.4 & 32635 & +1.8 & 25181 & +0.9 & 70808 & +2.9 & 5522403 & 4.3 \\
\hline
\end{tabular}

The components of the population growth in Selånger are quite clear from Table 3.

$\mathrm{T}$ a b 1 e 3 . Population growth divided into birth surplusage and migration net in Selånger $1861-1910$.

$\begin{array}{lcccccccc}\begin{array}{l}\text { Period } \\ \text { of time }\end{array} & \text { Births } & \text { Deaths } & \begin{array}{c}\text { Birth } \\ \text { surplus }\end{array} & \begin{array}{c}\text { Popu- } \\ \text { lation } \\ \text { growth } \\ \%\end{array} & \begin{array}{c}\text { In- } \\ \text { migra- } \\ \text { tion }\end{array} & \begin{array}{c}\text { Out- } \\ \text { migra- } \\ \text { tion }\end{array} & \begin{array}{c}\text { Migra- } \\ \text { tion } \\ \text { net }\end{array} & \begin{array}{c}\text { Popu- } \\ \text { lation } \\ \text { growth } \\ \%\end{array} \\ 1861-1870 & 397 & 316 & +81 & 100.0 & 627 & 634 & -7 & 0 \\ 1871-1880 & 582 & 351 & +231 & 48.3 & 966 & 719 & +247 & 51.7 \\ 1881-1890 & 712 & 422 & +290 & 48.7 & 1142 & 837 & +305 & 51.3 \\ 1891-1900 & 712 & 476 & +236 & 100.0 & 1157 & 1291 & -134 & 0 \\ 1901-1910 & 698 & 389 & +309 & 100.0 & 1478 & 1551 & -73 & 0\end{array}$


As a result of the good business cycles within agriculture and forestry Selånger almost doubled its population during the period. Especially the expansion in the $1870 \mathrm{~s}$ must be considered as remarkable. Despite the birth surplus during the 1870 s and 1880 s more than half of the population increase is due to the net migration.

Selångers in- and outmigration balance $1861-1910$ in absolute numbers and per mille of the medium population is shown in Table 4.

$\mathrm{T}$ a b 1 e 4. Selångers in- and outmigration together with net migration in absolute numbers and per mille of the medium population $1861-1910$.

$\begin{array}{lcccc}\begin{array}{l}\text { Period } \\ \text { of time }\end{array} & \begin{array}{c}\text { In- } \\ \text { migra- } \\ \text { tion }\end{array} & \begin{array}{c}\text { Out- } \\ \text { migra- } \\ \text { tion }\end{array} & \begin{array}{c}\text { Net } \\ \text { Absolute } \\ \text { numbers }\end{array} & \begin{array}{c}\text { Per } 1000 \text { of the } \\ \text { medium pop. }\end{array} \\ 1861-1865 & 382 & 311 & +71 & +9.52 \\ 1866-1870 & 245 & 323 & -78 & -10.33 \\ 1871-1875 & 482 & 334 & +148 & +18.07 \\ 1876-1880 & 484 & 385 & +99 & +10.68 \\ 1881-1885 & 441 & 398 & +43 & +4.18 \\ 1886-1890 & 701 & 439 & +262 & +22.13 \\ 1891-1895 & 619 & 761 & -142 & -11.00 \\ 1896-1900 & 538 & 530 & +8 & +0.63 \\ 1901-1905 & 629 & 716 & -87 & -6.55 \\ 1906-1910 & 849 & 835 & +14 & +1.03\end{array}$

During the most expansive period of the city of Sundsvall and the sawmill area Selånger could profit from the expansion of the center and take up a very independent role. Farmers from other areas moved into the parish: the number of farmers increased in 1865 from 128 to 191 in 1901 . The farmers, selling their growing surplus, a result of innovation in agriculture, to the expanding consumer market in the neighborhood, hired more hands and enlarged their household size and thus prevented outmigration of the labor force to the industrial and urban labor market. Many workers could also afford to stay in their native parish and take seasonal jobs in the industry. The whole community underwent, as has been shown, a rapid »modenization».

The migration field of Selånger became very untypical for rural districts with many migrants from very remote areas. The traditional short distance migration was replaced by long distance migration. In 1870 the immigration was recruited from 18 parishes, in 1890 from no less than 39. Even the outmigration field extended considerably: in 1870 the outmigration was directed towards 7 parishes, in 1890 towards 28 .

T a b l e 5. In- and out migration in Selånger during the years 1880, 1890, 1900, and 1910 in different types of communities. Net migration result of the communities.

\begin{tabular}{|c|c|c|c|c|c|c|c|c|c|c|c|}
\hline \multirow{2}{*}{$\begin{array}{l}\text { Type of } \\
\text { community }\end{array}$} & \multirow{2}{*}{\multicolumn{2}{|c|}{$\begin{array}{c}1880 \\
\text { IM OM }\end{array}$}} & \multicolumn{2}{|c|}{1890} & \multirow{2}{*}{\multicolumn{2}{|c|}{$\begin{array}{c}1900 \\
\text { IM OM }\end{array}$}} & \multicolumn{2}{|c|}{1910} & \multicolumn{2}{|c|}{ Tot } & \multirow[t]{2}{*}{ Net } \\
\hline & & & IM & OM & & & & $\mathrm{OM}$ & IM & $\mathrm{OM}$ & \\
\hline Agricultural & & 6 & 37 & 36 & 47 & 11 & 50 & 22 & 152 & 75 & +77 \\
\hline Agricultural mixed & 11 & 15 & 49 & 10 & 8 & 14 & 3 & 14 & 71 & 53 & +18 \\
\hline Industrial & 42 & 25 & 42 & 36 & 34 & 18 & 57 & 45 & 175 & 124 & +51 \\
\hline Towns & 25 & 25 & 39 & 60 & 8 & 39 & 61 & 83 & 133 & 207 & -74 \\
\hline Total & 96 & 71 & 167 & 142 & 97 & 82 & 171 & 164 & 531 & 459 & +72 \\
\hline
\end{tabular}


The most astonishing result is that Selånger showed migration gains against all sorts of rural communities (Table 5). Selånger even had migration gains during the 1870 s and 1880s against the sawmill parishes of the Sundsvall region. It is quite evident that Selånger acted as a sort of $» l o c k »$ for migrants on their way from the rural milieu to more urbanized areas. Traditional pull and push mechanisms must be modulated. The »modernization» of rural communities and its prevention of outmigration during the early phase of industrialization must be stressed.

\section{References}

Carlsson, G. (1969). Social mobility and class structure.

Chrisholm, M. (1968). Rural settlement and land use. Hutchinson University Library, London.

Eriksson, I. and Rogers, J. (1978). Rural labour and population change. Social and demographic developments in East-central Sweden during the Nineteenth century. Uppsala.

Herlitz, L. (1974). Jordegendom och ränta. Omfördelningen av jordbrukets merprodukt i Skaraborgs län under frihetstiden. Lund.

Hägerstrand, T. (1957). En landsbygdsbefolknings flyttningsrörelser. Studier över migrationen på grundval av Asby sockens flyttningslängder 1840-1944. (Lund, Univ., Geogr. inst., Meddel. Serie C. nr 251. Lund).

Kronborg, B.; and Nilsson T. (1975). Stadsflyttare. Industrialisering, migration och social mobilitet med utgångspunkt frản Halmstad, 1870-1910. Uppsala.

Nilsson, F. (1970). Emigration frản Stockholm till Nordamerika 1880-1893. En studie i urban utvandring. Stockholm.

Norberg, A. and Åkerman, S. (1973). Migration and the Building of families (Aristocrats, Farmers, Proletarians. Essays in Swedish Demographic History, Uppsala, s. 88-119).

Norman, H. (1974). Från Bergslagen till Nordamerika. Studier i migrationsmönster, social rörlighet och demografisk struktur med utgångspunkt från Örebro län 1851-1915. Uppsala.

Population movements and industrialization. Swedish counties 1895-1930. (1941). By the staff of the institute for social sciences, Stockholm university (Stockholm economic studies 10:2. London).

Rolén, M. (1979). Skogsbygd i omvandling. Studier kring befolkningsutveckling, omflyttning och social rörlighet i Revsunds tingslag 1820-1977. Uppsala.

Rondahl, B. (1972). Emigration, folkomflyttning och säsongarbete i ett sågverksdistrikt i södra Hälsingland 1865-1910. Uppsala.

Tedebrand, L-G. (1972). Västernorrland och Nordamerika 1875-1913. Utvandring och áterinvandring. Uppsala.

Tedebrand, L-G. (1983). Selånger. En sockens historia. Sundsvall.

Thomas, B. (1954). Migration and economic growth. A study of Great Britain and the Atlantic economy. Cambridge University Press.

Thomas, D. S. (1941). Social and economic aspects of Swedish population movements 1750-1933. New York.

Wrigley, E. A. (1972). The process of modernization and the industrial revolution in England (The Journal of Interdisciplinary History 3/1972/p. 226-.) 